(REVIEW ARTICLE)

\title{
Environmental impact assessment in Nigeria- A review
}

\begin{abstract}
Abdullateef Abdullahi Ibrahim 1,* Abbas Sani 2, Ali Mustapha Gado 3, Muhammad Abdullahi Ibrahim 4, Mustapha Said Sulaiman ${ }^{1}$ and Idris Umar Zungum ${ }^{1}$

${ }^{1}$ Department of Biological Sciences, Faculty of Science, Bayero University, Kano, P.M.B. 3011, Kano, Nigeria.

2 Department of Biochemistry, Faculty of Basic Medical Sciences, Bayero University, Kano, P.M.B. 3011, Kano, Nigeria.

${ }^{3}$ Dikwa Bio-resource Centre, National Biotechnology Department Agency, Ministry of Science and Technology, Nigeria.

${ }^{4}$ Department of Biological Sciences, Faculty of Science, University of Maiduguri, P.M.B. 1069, Borno, Nigeria.
\end{abstract}

Publication history: Received on 14 December 2020; revised on 21 December 2020; accepted on 23 December 2020

Article DOI: https://doi.org/10.30574/wjarr.2020.8.3.0487

\begin{abstract}
Environmental Impact Assessment (EIA) is an essential tool used for decision making in a developmental projects as well as a systematic process to identify, predict and evaluate the environmental effects of the proposed actions and projects; the process is applied prior to major decisions and commitments being made. This paper makes a systematic review of the challenges relating to the application of Environmental Impact Assessment in Nigeria, in order to achieve sustainable development. The present review describes the laws, basic principles, procedures, sustainability and impact of EIA on biological aspect, meanwhile the paper also emphasises on the constraints of EIA in Nigeria.
\end{abstract}

Keywords: Environment; Sustainable development; Ecosystem; Oil and Gas

\section{Introduction}

The natural environment is an emporium of resources; both renewable and non-renewable [1]. There is need to use the environmental resources in a sustainable approaches, among which is conducting Environmental Impact Assessment in every environmental projects before and after the project. However, significant proportion of population in developing countries relies on environmental resources [2].

Environmental impact assessment (EIA) is an assessment of the possible positive and negative impact that a proposed project may have on the environment [3].

The Environmental Impact Assessment (EIA) has evolved and become part of major project requirements in numerous countries. However, its contribution to sustainable development and reduction in poverty levels of people affected by projects has not been assessed in developing countries [4,5]. EIA is also considered as the official appraisal process to identify, predict, evaluate and justify the ecological, social, and related biophysical effects of a proposed policy, program or project on the environment [3].

According to Anago [6] Ever since the 1972 Stockholm UN conference on the Human Environment, which established the nexus between under development and environmental integrity, environmental issues have become transnational.

As stated by Owoyemi and Bamigboye [7] to achieve sustainable development in any activity in Nigeria, EIA is key tool for main-streaming environmental concerns into development process. Nigeria is one of the few developing countries that have specific relevant legislation as enacted in the 1992 EIA act.

\footnotetext{
* Corresponding author: Abdullateef Abdullahi Ibrahim; Phone: +(234) 7083333163; E-mail: abdullateefgaya@gmail.com Department of Biological Sciences, Faculty of Science, Bayero University, Kano, P.M.B. 3011, Kano, Nigeria.
} 
Hence, the environment is threatened severely by so many problems, some of which are caused by the activities of Construction Projects [8].

In 2011, the United Nations Environmental Programme released an independent assessment report establishing that decades of oil and gas exploration and production activities by multinational oil companies have caused severe pollution of the ecosystem in the Niger Delta [9].

The dumping of hazardous wastes in 1989 into Koko Port crystallised in the formulation of two foremost decrees on the environment by the federal government of Nigeria; before this period, government had been adamant about the necessity for a sound legal framework towards sustainable environment. The consequence of toxic waste disposal brought about the enactment of the Federal Environmental Protection Agency, (FEPA) decree No 58 of 1988 and amended in 1992 as decree no 59. Also, the Harmful Waste Decree No 42 of 1988 was promulgated to address harmful waste disposal. The essence of these decrees subsequently led to the establishment of different bodies and legal frameworks dealing with environmental matters in the country [10].

\section{EIA and Sustainability}

Environmental Impact Assessment (EIA) has evolved and become part of major project requirement in many countries including Nigeria for the attainment of sustainable development and reduction of poverty levels of people affected by projects [5].

For development to be sustainable it should meet the emerging needs of the present and succeeding generations [7]. Environmental Impact Assessment (EIA) is also considered as the official appraisal process to identify, predict, evaluate and justify the ecological, social, and related biophysical effects of a proposed policy, program or project on the environment [3].

\section{Environmental laws in Nigeria}

Nigeria (Africa's most populous nation), got independent since 1960, occupies an area of $923,768 \mathrm{~km}^{2}$ with varied climates and seasons. Presently, its 2015 estimated population is over 182,202,000 million people while 2006 population census is 140,431,790 million people. Prior to oil, agriculture (before 1970) was the economic mainstay [5].

As a consequence of the illegal dumping of toxic wastes in Koko, in the former Bendel State, in 1987, the Nigerian Government promulgated the Harmful Wastes Decree which provides the legal framework for the effective control of the disposal of toxic and hazardous waste into any environment within the confines of Nigeria. This was immediately followed by the creation of a regulatory body, the Federal Environmental Protection Agency (FEPA) in 1988 [11].

FEPA serves as a regulatory agency with the overall responsibility of protecting and developing the Nigerian environment. It also puts into action a National Policy that was developed as the main document for the preservation and protection of Nigeria's environment. Additionally, a National Policy Plan (NPP) was published in 1989, with the goal of achieving sustainable development. This development is in line with sectoral regulations including the National Environmental Protection (Pollution Abatement in Industries and Facilities Generating Wastes, Regulation of 1991). As a result of the regulation, EIA became mandatory only when demanded by FEPA, from then EIA became an indispensable prerequisite for the effective implementation of the national policy on the environment, and further directed that EIA be made mandatory for all development projects with effect from March 1991. The body also made environmental auditing mandatory for all existing industries all over the country [12].

Although environmental legislation commenced after the discovery of petroleum, public awareness of the areas of the environment that required development remained limited. Neither the general public nor the government understood technical issues like effluent limitations, pollution abatement, and the overall modalities for the sustainable development of Nigeria's environmental resources.

Petroleum is the major foreign exchange earner of the Nigerian government. Since 1956, petroleum exploration activities have caused very severe consequences that have required a steady stream of laws and subsidiary regulations that strive to address these consequences. In the earlier years of oil exploration and into the 1990s, oil spillages were reported to have been of such great magnitude as to adversely affect local agricultural and fishing activities. Between 1976 and 1988, two thousand reports of spillages, causing an estimated loss of two million barrels of oil, were recorded nationwide. In 1999, in response to concerted efforts to compensate affected communities, the Niger-Delta 
Development Commission Act established the Niger Delta Commission to tackle ecological problems that arose from the exploration of oil minerals within the Niger Delta.

\section{Basic Principles}

Environmental Impact Assessment should be:

Focused - the process should concentrate on significant environmental effects and key issues; i.e., the matters that need to be taken into account in making decisions.

Purposive - the process should inform decision making and result in appropriate levels of environmental protection and community well-being.

Practical - the process should result in information and outputs which assist with problem solving and are acceptable to and able to be implemented by proponents.

Rigorous - the process should apply "best practicable" science, employing methodologies and techniques appropriate to address the problems being investigated.

Cost-effective - the process should achieve the objectives of EIA within the limits of available information, time, resources and methodology.

Relevant - the process should provide sufficient, reliable and usable information for development planning and decision making.

Interdisciplinary - the process should ensure that the appropriate techniques and experts in the relevant bio-physical and socio-economic disciplines are employed, including use of traditional knowledge as relevant.

Efficient - the process should impose the minimum cost burdens in terms of time and finance on proponents and participants consistent with meeting accepted requirements and objectives of EIA.

Credible - the process should be carried out with professionalism, rigor, fairness, objectivity, impartiality and balance, and be subject to independent checks and verification.

Adaptive - the process should be adjusted to the realities, issues and circumstances of the proposals under review without compromising the integrity of the process, and be iterative, incorporating lessons learned throughout the proposal's life cycle.

Integrated - the process should address the interrelationships of social, economic and biophysical aspects.

Participative - the process should provide appropriate opportunities to inform and involve the interested and affected publics, and their inputs and concerns should be addressed explicitly in the documentation and decision making.

Transparent - the process should have clear, easily understood requirements for EIA content; ensure public access to information; identify the factors that are to be taken into account in decision making; and acknowledge limitations and difficulties.

Systematic - the process should result in full consideration of all relevant information on the affected environment, of proposed alternatives and their impacts, and of the measures necessary to monitor and investigate residual effects [13].

\section{Procedure of EIA in Nigeria}

The screening and monitoring steps of the EIA process deserve special attention [14].

The main advantages and benefits of EIA are:

- A positive contribution towards achieving sustainability;

- Increased accountability and transparency during the development process

- Improved project design/siting;

- Reduced environmental damage;

- More informed decision-making (with improved opportunities for public involvement in decision-making)

- More environmentally sensitive decisions

- Improved integration of projects into their environmental and social setting; and

- More effective projects in terms of meeting their financial and/or socio-economic objectives [15]. 


\section{Impact of EIA on Biological Aspect}

Another vital principle is that of biological integrity. This principle first appeared in 1972 in the US Federal Water Pollution Control Act also known as Clean Water Act. At first, its definition was narrowly applied to fish and wildlife conservation. But of recent, biological integrity has been extended to all forms of life in various ecosystems [10].

The oil rich regions such as Nigeria have a greater effect of most of these environmental degradation challenges in areas such as: oil spillage; crude oil content chemical substances as sulphur nitrogen, oxygen as well as hydrocarbon component, oil spillage affect living things connect with their life, aquatic life plant life directly or indirectly. Thereby, being implications for the bio-diversity of all living things now and in future [16].

\section{Challenges and Constraints of EIA in Nigeria}

Experience especially in respect of infrastructural projects has shown that EIA is hardly undertaken prior to the approval of most projects in Nigeria. Hence, Building construction projects in Nigeria have both direct and indirect impacts on the environment [8].

There is delay in the execution of EIA in Nigeria due to the inadequacies and misinterpretations of various regulatory statutes. There is duplication of functions and overlapping responsibilities in processes and procedures guiding the execution of the various impact assessment tasks due to too many regulatory bodies (FME NESREA, NOSDRA, DPR, states EBP).

Among Challenges of EIA according to Owoyemi and Bamigboye, [7] are highlighted below:

- Lack of credibility and transparency

- Absence of effective Sanctions

- Abuse of the exclusion clause in the EIA act

- A large percentage of Nigerian populace is unaware of EIA provisions and their rights of objection to environmentally unfriendly prospective projects during the 21 days public display of EIA drafts

Nigeria has serious environmental degradation resulting from pollution related to the oil and gas industry [13]. Another source of environmental impact is Burning coal to produce steam for electricity. Large amounts of Green house gases (GHG) as well as causing local environmental damage [8]. These are challenges which are bedeviling the standard of the environment and ecosystem at large; therefore, the need of application of EIA in these satiations is inevitable.

Many small and medium-scale enterprises (SMSE) create hazardous wastes, e.g. lead from small-scale lead mining in Zamfara State; Northern Nigeria caused a high number of deaths at list 163 dead including 111 children and 355 cases discovered. Investigation showed that the people had been digging for gold at the times of their deaths, in an area where lead is prevalent. It is thought that the poisonings were caused by the illegal extraction of ore by villagers, who take crushed rock home with them to extract [5].

\section{Bodies and Legal Frameworks Responsible for Environmental Activities in Nigeria}

In Nigeria, as part of the measures taken by the government to preserve the environment and its resources, protect Nigerians from hazardous and wastes ecological nuisance, to fight and prevent pollution in Nigeria, the federal government of Nigeria and several Nigerian States have established various agencies and organisations.

These agencies are guided by and function in accordance with the all the environmental laws and acts in Nigeria. Below is a compilation of all the environmental agencies and associated agencies (federal, state and NGOs) in the country:

- Abia State Environmental Protection Agency

- Abia State Ministry of Environment, Umuahia

- Abuja Environmental Protection Agency

- Abuja Environmental Protection Board (AEPB)

- Adamawa State Ministry of Environment, Yola

- Akwa Ibom State Ministry of Environment and Mineral Resources, Uyo

- Anambra State Environmental Protection Agency 
- Anambra State Ministry of Environment, Mineral Resources, Science and Technology, Akwa

- Bauchi State Environmental Protection Agency, Bauchi

- Bayelsa State Environmental Sanitation Authority, Yenagoa

- Bayelsa State Ministry of Environment

- Benue State Environmental Sanitation Authority (BENSESA), Makurdi

- Borno State Ministry of Environment, Maiduguri

- Borno State Rural Water and Sanitation Agency, Maiduguri

- Cross River Ministry of Environment, Calabar

- Delta State Environmental Protection Agency

- Delta State Waste Management Board, Asaba

- Department of Petroleum Resources

- Ebonyi State Ministry of Health and Environmental, Abakaliki,

- Edo State Environmental and Waste Management Board, Benin City

- Ekiti State Waste Management Board, Ado Ekiti

- Enugu State Environmental Protection Agency

- Enugu State Waste Management Authority, Enugu

- Environmental Health Officers Registration Council of Nigeria

- Federal Environmental Protection Agency (FEPA)

- Federal Ministry of Environment (FMOE)

- Federal Ministry of Environment, Housing and Urban Development (FMEHUD)

- Forestry Research Institute of Nigeria (FRIN)

- Friends of the Environment Nigeria (NGO)

- Gombe State Environmental Sanitation and Protection Agency, Gombe

- Gombe State Ministry of Water Resources and Environment, Gombe

- Ibadan Waste Management Authority, Ibadan

- Imo State Bureau for Sanitation and Transport

- Imo State Environmental Protection Agency

- Imo State Ministry of Petroleum and Environment, Owerri

- Jigawa State Ministry of Environment, Dutse

- Jigawa State Rural Water Supply and Sanitation Agency, Dutse.

- Kaduna State Environmental Protection Agency

- Kaduna State Ministry of Environment and Natural Resources, Kaduna

- Kaduna State Waste and Sanitation Project, Kaduna

- Kano State Environmental Protection Agency

- Kano State Refuse Management and Sanitation Board (REMASAB), Kano

- Kano State Rural Water Supply and Sanitation Agency (RUWASA), Kano

- Katsina State Rural Water Supply and Sanitation Agency, Katsina

- Kebbi State Ministry of Environment, Birnin Kebbi

- Kogi State Environmental Protection Board, Lokoja

- Kogi State Ministry of Environment and Physical Planning Development, Lokoja

- Kogi State Sanitation and Water Management Board, Lokoja

- Kwara State Environmental Protection Agency, Ilorin

- Kwara State Ministry of Environment and Tourism, Ilorin

- Lagos State Environmental Protection Agency (LASEPA)

- Lagos State Government Ministry of the Environment

- Lagos State Waste Disposal Board (LSWDB)

- Lagos State Waste management Agency operatives (PSP)

- Lagos State Waste Management Authority (LAWMA)

- Ministry of Water Resources

- National Biosafety Management Agency (NBMA)

- National Emergency Management Agency (NEMA)

- National Environmental Standards and Regulations Enforcement Agency (NESREA)

- National Oil Spill Detection and Response Agency (NOSDRA)

- Niger State Environmental Protection Agency, Minna

- Nigeria Hydrological Services Agency (NIHSA)

- Nigerian Conservation Foundation (NCF) 
- Ogun State Environmental Protection Agency, Abeokuta

- Ogun State Ministry of Environment, Abeokuta

- Ondo State Waste Management Authority, Akure

- Osun State Environmental Protection Agency, Osogbo

- Osun State Ministry of Environment, Osogbo

- Oyo State Environmental Protection Commission

- Oyo State Ministry of Environment and Water Resources, Ibadan

- Plateau Rural Water Supply and Sanitation Agency, Jos

- Plateau State Environmental Protection and Sanitation Agency, Jos

- River basin Authority (Federal Ministry of Water Resources)

- River State Environmental Protection Agency

- River State Environmental Sanitation Authority, Port Harcourt

- River State Ministry of Environment, Port Harcourt

- State Environmental Protection Agencies (SEPAs)

- State Ministries of Environment

- Taraba State Environmental Protection Agency, Jalingo

- Taraba State Rural Water Supply and Environmental Sanitation Agency, Jalingo

- Urban Development Board

- Waste Management Society of Nigeria

- Waste Management Society of Nigeria, Akwa Ibom

- Waste Management Society of Nigeria, Benue State

- Waste Management Society of Nigeria, Delta State

- Waste Management Society of Nigeria, FCT

- Waste Management Society of Nigeria, Kano State

- Waste Management Society of Nigeria, Lagos State

- Waste Management Society of Nigeria, Niger State

- Waste Management Society of Nigeria, Ondo State

- Yobe State Environmental Protection Agency, Damaturu

- Yobe State Ministry of Environment, Damaturu

- Zamfara State Ministry of Environment and Solid Minerals Development, Zamfara

\section{Conclusion}

Nigeria is among the richest countries in terms of environmental natural resources in Africa and in the world at large, the country is blessed with huge mineral resources; which include crude oil, gold, iron ore, tin, lead and zinc and more other. Hence, the exploration and utilization of the resources might affect the stability of the environment and the ecological system, therefore the consideration of eco-friendly and environmental friendly measures during any sort of activity on environment should not be over emphasised.

\section{Recommendations}

Environmental impact assessment should be given adequate budgetary funding always. The regulations and laws should be reviewed by expertise periodically. There must be check and balance in the environmental sectors in Nigeria in order to ensure proper environmental monitoring and control. Researchers need to put emphasis in finding mitigation measures of environmental pollution using technological mechanisms and scientific approaches in sustainable ways. Efficient and effective implementation of environmental settled laws should be considered by government or individuals before and after projects.

\section{Compliance with ethical standards}

\section{Acknowledgments}

This work was supported by Petroleum Technology Development Fund (PTDF). We cannot express enough thanks to PTDF for their continued support and encouragement by awarding us scholarship at M Sc level. We offer our sincere appreciation for the award that enables us to write this review paper. Thank you so much for the support. 


\section{Disclosure of conflict of interest}

All authors declares no conflict of interest is exist.

\section{References}

[1] Alaoma A, Voulvoulis N. Mineral resource active regions: The need for systems thinking in management. 2018.

[2] Kankara AI. Examining environmental policies and laws in Nigeria. Int. J. Environ. Eng. Manage. 2013; 4: 165170.

[3] Anulika NP, Osaze O, Abiola AH, Ignatius EO. The Role of Environmental Impact Assessment in Environmental Sustainability of Onitsha Metropolis in Anambra State, International Journal of Technology Enhancements and Emerging Engineering Research. 2015; 3(11): 109-114.

[4] Betey CB, Essel G. Environmental impact assessment and sustainable development in Africa: a critical review. 2013.

[5] Onuora UD, Eze AV, Ugboji NB. Environmental Impact Assessment: A Veritable Tool for Sustainable Development in Nigeria. IOSR Journal of Applied Chemistry (IOSR-JAC). 2017; 10(9): 38-43.

[6] Anago I, Nigeria IA. Environmental impact assessment as a tool for sustainable development: the Nigerian experience. In FIG XXII Congress of the International Federation of Surveyors. 2002.

[7] Owoyemi O, Bamigboye O. Contemporary environmental impact assessment issues in Nigeria. RMZ - M\&G. 2013; 60: 219-224.

[8] Ijigah EA, Jimoh RA, Aruleba BO, Ade AB. An Assessment of Environmental Impacts of Building Construction Projects; Civil and Environmental Research. 2013; 3(1): 93-105.

[9] Duru CU. Environmental degradation: Key challenge to sustainable economic development in the Niger Delta. 2014.

[10] Akamabe UB, Kpae G. A critique on Nigeria national policy on environment: Reasons for policy review. International Journal of Geography and Environmental Management. 2017; 3(3): 22-36.

[11] Echefu N, Akpofure E. Environmental impact assessment in Nigeria: regulatory background and procedural framework. EIA Training Resource Manual. 2002; 63-74.

[12] Isah MN. The Role of Environmental Impact Assessment in Nigeria's Oil and Gas Industry, (Doctoral dissertation, Cardiff University). 2012; 1-193.

[13] Senécal P, Goldsmith B, Conover S, Sadler B, Brown K. Principles of Environmental Impact Assessment Best Practice, International Association for Impact Assessment in cooperation with Institute of Environmental Assessment, UK. 1999.

[14] Nugent C. Review of environmental impact assessment and monitoring in aquaculture in Africa. FAO. Environmental impact assessment and monitoring in aquaculture. FAO Fisheries and Aquaculture Technical Paper. 2009; 527: 59-151.

[15] Abaza H, Bisset R, Sadler B. Environmental impact assessment and strategic environmental assessment: towards an integrated approach. UNEP/Earthprint. 2004.

[16] Akintoye VA, Opeyemi OA. Prospects for Achieving Sustainable Development Through the Millennium Development Goals in Nigeria. European Journal of Sustainable Development. 2014; 3(1): 33-33. 